\title{
Analisis Implementasi Supervisi Kepala Sekolah dalam Meningkatkan Kompetensi Guru di SMA Negeri 5 Pematangsiantar
}

\author{
${ }^{*}$ Amini ${ }^{1}$, Sri Kesumawaty ${ }^{2}$, Salim Aktar ${ }^{3}$ \\ ${ }^{1}$ (Dosen Magister Manajemen Pendidikan Tinggi UMSU, Indonesia) \\ ${ }^{2}$ (Mahasiswa Magister Manajemen Pendidikan Tinggi UMSU, Indonesia) \\ ${ }^{3}$ (Dosen Magister Manajemen Pendidikan Tinggi UMSU, Indonesia)
}

* Corresponding Author. E-mail: ${ }^{1}$ amini@umsu.ac.id, ${ }^{2}$ srikesumawaty.tsps@gmail.com, ${ }^{3}$ salimaktar@umsu.ac.id

\begin{abstract}
Abstrak
Permasalahan dalam Penelitian ini adalah menunjukkan bahwa belum optimalnya proses pembelajaran khususnya, dalam kompetensi pedagogik, kompetensi profesional, kompetensi sosial, kompetensi kepribadian dalam meningkatkan kompetensi guru di SMA Negeri 5 Pematangsiantar. Tujuan Penelitian ini menggunakan pendekatan kualitatif. Dimana peneliti langsung meneliti ke lapangan. Dengan menggunakan teknik pengumpulan data berupa observasi, wawancara dan studi dokumentasi yang dilakukan di SMA Negeri 5 Pematangsiantar. Adapun informan penelitian ini berjumlah 4 orang yaitu: kepala sekolah, wakil kepala sekolah dan guru mata pelajaran. Untuk menganalisis data menggunakan model analisis interaktif Miles dan Huberman, yaitu reduksi data, penyajian data dan penarikan kesimpulan. Untuk memeriksa keabsahan data menggunakan uji credibility dengan, menggunakan teknik triangulasi, uji transferability, dependability, dan confirmability. Hasil penelitian ini mengungkapkan tiga temuan yaitu: (1) perencanaan program supervisi yang dilakukan kepala sekolah dalam meningkatkan kompetensi guru sudah tersusun dengan benar sesuai dengan ketentuan yang ada, (2) teknik supervisi yang dilakukan kepala sekolah dalam meningkatkan kompetensi guru adalah dengan menggunakan teknik supervisi secara individu dan kelompok, (3) evaluasi supervisi yang dilakukan kepala sekolah dalam meningkatkan kompetensi guru dilihat dari kinerja yang ditunjukkan guru, dengan adanya kegiatan supervisi ini guru sangat terbantu dalam menghadapi setiap masalah yang dihadapi berkaitan dengan kegiatan pembelajaran.
\end{abstract}

Kata Kunci: Supervisi, Kepala Sekolah, Kompetensi Guru

\begin{abstract}
The problem of this researeh is to show that the learuing process is not as maximal as hoped in pedagogic competency,professional competency, sosial competency, and attitude competency in improving the teacher's competency at SMA Negeri 5 Pematangsiantar.

The aim of this study uses qualitative approach where by the researcher conducted the research directly in the field. The technique of data collecting was by observing, interviewing and doing documentation study at SMA Negeri 5 Pematangsiantar. The informan in the this research are the principal, the vice principal and the discipline teacher. The interactive analisys model of miles and Huberman was used to analyse the data, data reduction, data presentation and conclusion. The tringulation technique, transferability test, dependability, and confirmability were used to verify the validity of the data.The findings of this study revealed three things, (1) the supervision program planning which was conducted by the principal in increasing the teacher's competence that had been arranged correctly based on the existing provisions, (2) the supervision technique which was conducted by the principal in increasing the teacher's competence was by using supervision technique individually and group,(3) the evalution of the supervision done by the principal in increasing the teacher's competence was marked by the teacher's performance. By Conducting this supervision program, it helped the teachers in facing every problem concerned with the learning process.
\end{abstract}




\section{Pendahuluan}

Mutu ilmu pendidikan dipercaya sebagai peluasan wahana dalam akses mobilitas sosial yang ada di masyarakat baik secara vertikal maupun horizontal Dimana pendidikan merupakan aspek yang sangat penting bagi perkembangan sumber daya manusia, karna pendidikan merupakan wahana atau salah satu instrumen yang digunakan bukan saja untuk membebaskan manusia dari keterbelaangan, melainkan juga dari kebodohan serta kemiskinan. Dimana kemajuan bangsa Indonesia dapat dicapai melalui pendidikan yang lebih baik. serta mutu pendidikan diharapkan dapat menaikkan harkat dan martabat manusia dalam upaya meningkatkan kompetensi guru.

Ditengah diera globalisasi ini menuntut semua bidang kehidupan untuk menyesuaikan visi dan misi serta tujuan dan strategi agar dapat menyesuaikan kebutuhan, Khususnya di dalam pendidikan agar tidak ketinggalan zaman. Maka Perubahan sistem pendidikan nasional senantiasa terus berkembangkan sesuai dengan kebutuhan dan perkembangan zaman baik di tingkat lokal, nasional, maupun global. Salah satu contoh pentingnya dari sistem pendidikan adalah guru, karena guru komponen pendidikan yang sangat bersentuhan langsung pada perserta didik. Baik ataupun buruknya hasil dari sebuah proses pembelajaran sangat ditentukan oleh kemampuan seorang guru dalam mengelola proses pembelajaran.

Untuk dapat melakukan tugas dan tanggung jawabnya dengan baik, maka seorang guru harus mempunyai sejumlah kompetensi atau pun menguasai sejumlah pengetahuan yang cukup baik, sikap, dan keterampilan yang terkait dengan bidang atau pun tugasnya. Kompetensi yang harus dimiliki oleh guru dapat mencakup kompetensi pedagogik, kompetensi kepribadian, kompetensi sosial, dan kompetensi profesional.
Menurut perspektif kebijakan nasional, pemerintah telah merumuskan empat jenis komponen guru, sebagaimana tercamtum dalam Penjelasan Peraturan Pemerintah No.19 Tahun 2005 tentang Standar Nasional Pendidikan, yaitu: kompetensi pedagogik, kompetensi kepribadian, kompetensi sosial, kompetensi profesional.

Pengawasan juga sering dikatakan dengan supervisi, adalah salah satu fungsi pendidikan bertujuan untuk menjaga serta mendorong agar pelaksanaan kegiatan belajar mengajar disekolah dapat berjalan dengan baik dan lancar dan, berhasil sesuai dengan peraturan perundangan yang ada berbagai macam kompetensi guru yaitu: Kompetensi pedagogik adalah berkaitan dengan kemampuan menggolah pembelajaran baik, sedangkan kompetensi kepribadian adalah kemampuan pribadi yang mantap, berakhlak mulia, dan berwibawah dan menjadikan contoh teladan kepada perserta didik, Kompetensi sosial berkaitan dengan kemampuan yang berhubungan dengan pribadi dalam kehidupan bermasyarakat. Sedangkan kompetensi profesional adalah kemampuan untuk penguasaan materi pembelajaran di bidang keahliannya masingmasing. Guru yang mempunyai kompetensi akan dapat terlihat dalam pelaksanaan tugas dan tanggung jawabnya disekolah tempat dimana bertugas.

Kepala sekolah juga seorang peminpin yang mendapat tugas yang berat dalam rangkah meningkatkan kwalitas mutu sekolah, dan guru juga harus memiliki kompetensi baik, Karena mutu pendidikan meningkat hal itu dapat dilihat dari guru-guru yang mempunyai kualitas yang baik, Oleh karena itu masyarakat dapat melihat hasil yang diraih karena mendidik adalah tugas dari seorang guru, oleh itu guru harus memiliki kemampuan yang tidak dapat diserahkan kepada semua orang.

Sahartian 2010: 19 mengatakan bahwa supervisi bertujuan memberikan layanan dan bantuan untuk meningkatkan kualitas belajar 
mengajar dikelas pada gilirannya untuk menghasilkan kualitas belajar siswa. Supervisi memiliki dasar yang kuat bagi strategi pembinaan profesional guru. Ada dua alasan yang menguatkannya, langkah pertama supervisi memiliki produsen jadi untuk pembinaan memerlukan proses dan langkah. Langkah kedua supervisi sebagai konsep pembinaan. Adapun tujuan elemen konseptual, yaitu : (1) supervisi adalah perlakuan yang disengaja terhadap proses pembelajaran, (2) menciptakan produktifitas baik bagi guru maupun bagi supervisior, (3) mempersoalkan pengetahuan dan pelatihan bagi para supervisor, (4) supervisi adalah suatu teknologi untuk perbaikan dan peningkatan mutu pembelajaran siswa dan pengajaran guru, (5) sifatnya berorientasi pada tujuan, sistematik dan luwes, (6) mempersyaratkan dan saling percaya dan memelihara hubungan, dan (7) membantu penjelasan dan menggambarkan peran masing-masing bentuk layanan profesional yang diberikan oleh supervisor (Pengawasan Sekolah, Kepala Sekolah dan Pembinaan lainya).

\section{Dalam}

$$
\text { meningkatkan }
$$

proses

pembelajaran dan dalam rangkah memperbaiki mutu pendidikan kepala sekolah SMA Negeri 5 Pematangsiantar Bertanggungjawab dalam kegiatan supervisinya. Melaksanakan tugas kegiatan supervisi sangatlah penting karena melalui peran kepala sekolah sebagai supervisor dapat memberikan bantuan, bimbingan, ataupun layanan kepada guru dalam menjalankan tugas dalam memecahkan permasalahan yang dihadapinya dalam pembelajaran. Salah satu upaya untuk meningkatkan kompetensi guru yaitu dengan cara melakukan supervisi. Supevisi ini dapat membantu guru untuk meningkatkan kompetensi guru, melalui pembahasan secara berdua atau kelompok tentang kajian masalah pengembangan untuk menentukan solusi dalam berbagai alternatif pengembangan untuk meningkatkan kompetensi guru tersebut.
Supervisi atau pengawasan yang dilakukan kepala sekolah SMA Negeri 5 Pematangsiantar merupakan salah satu fungsi administrasi pendidikan, Bertujuan untuk menjaga dan mendorong agar peningkatan kegiatan belajar mengajar guru disekolah dapat berjalan dengan baik, sesuai dengan peraturan perundang-undangan yang berlaku.

SMA Negeri 5 Pematangsiantar adalah salah satu dari sekolah SMA Negeri yang berada di Kota Pematangsiantar yang melaksanakan kegiatan supervisi untuk meningkatkan kompetensi guru.

Didalam pemantauwan seorang kepala sekolah harus benar-benar dibutukan oleh para guru untuk meningkatkan kompetensi guru. Hal ini mengingatkan tugas kepala sekolah sebagai supervisor maka sudah menjadi tugas dan tanggungjawabnya sebagai kepala di SMA Negeri 5 Pematangsiantar untuk dapat melaksanakan supervisi terhadap guru di sekolah SMA Negeri 5 Pematangsiantar itu.

Pada hakikatnya supervisi adalah suatu kegiatan pembinaan terhadap guru dan tenaga kependidikan melalui teknik dan tujuan untuk menciptakan efektivitas guru dalam menjalankan tugasnya dengan baik, serta aktivitas pembinaan yang direncanakan untuk membantu para guru dan pengawai sekolah agar memberikan layanan kepada guru baik secara individu dan kelompok dalam memperbaiki kompetensinya.

Di Kota Pematangsiantar terdapat 6 (enam) sekolah Negeri yang terdiri dari SMA Negeri 1, SMA Negeri 2, SMA Negeri 3, SMA Negeri 4, SMA Negeri 5 dan SMA Negeri 6. SMA Negeri 5 selalu melaksanakan supervisi untuk meningkatkan kompetensi guru.

Peningkatan kompetensi guru dilakukan melalui supervisi dan monitoring pengawasan bukan sekerdar diarahkan kepada pembinaan, yang lebih bersifat aspek administratif.

E. Mulyasa ( 2011) mengatakan bahwa untuk mengetahui sejauh mana guru maupun melaksanakan pembelajaran secara berkala, kepala seolah perlu melaksanakan kegiatan 
supervisi, yang dapat dilakukan melalui kegiatan kunjungan kelas untuk mengamati proses pembelajaran secara langsung, terutama dalam pemilihan dan penggunaan metode, media yang digunakan dan keterlibatan siswa dalam proses pembelajaran. Dari hasil supervisi ini, dapat diketahui kelemahan sekaligus keunggulan guru dalam melaksanakan pembelajaran tingkat penguasaan kompetensi guru yang bersangkutan, selanjutnya diupayakan solusi, pembinaan dan tindak lanjut tertentu sehingga guru dapat memperbaiki kekurangan yang ada sekaligus mempertahankan keunggulannya dalam melaksanakan pembelajaran., Kepala sekolah memiliki peran strategi untuk meningkatkan mutu pendidikan di lembaga yang dipimpinnya. Kepala sekolah tidak saja berperan sebagai pemimpin pembelajaran, Tetapi lebih dari itu ia merupakan pemimpin keseluruhan fungsifungsi kepemimpinan.

Hal tersebut diperkuat oleh Permendiknas No.13 Tahun 2007 mengenai standar kepala sekolah yang telah mencantumkan 5 kompetensi yang harus dimiliki oleh kepala sekolah yaitu kompetensi kepribadian, kompetensi manajeril, kompetensi kewirausahaan, kompetensi supervisi dan juga kompetensi sosial. Ramburambu penilaian kinerja kepala sekolah Dirjen Dikdasmen Tahun 2000 yaitu: 1) Kemampuan menyusun program supervisi pengajaran, 2) Kemampuan melaksanakan program supervisi pengajaran, serta 3) Kemampuan memanfaatkan hasil supervisi.

Kinerjanya tinggi disebut sebagai orang yang produktif, sebaliknya seseorang yang tingkat kinerjanya tidak mencapai standar dikatakan sebagai orang yang tidak produktif atau kenerjanya rendah. Sementara itu Robert L.Katz (dalam Donni Juni Priansa) mengemukakan bahwa setiap manajer membutuhkan minimal tiga keterampilan dasar. Ketiga keterampilan manajerial tersebut sangat aplikatif untuk diadopsi bagi guru. Ketiga keterampilan tersebut adalah keterampilan konseptual, kerampilan kemanusiaan,serta keterampilan teknis. Menurut Peter F.Oliva Sebagaimana dikutif oleh Piet A Sahertian mengatakkan bahwa seorang supervisor dapat berperan sebagai: (1) Koodinator;(2) Konsultan;(3) Pemimpin kelompok; (4) Evaluator. Sebagai koodinator ia dapat mengkoodinasi program belajar mengajar, tugas-tugas anggota staf berbagai kegiatan yang berbeda-beda antara guruguru.

Sebuah organisasi dibutuhkan sebuah komitmen bersama, Kebersamaan dapat terbentuk apabila terjadi hubungan yang baik terbangun berawal dari sebuah komunikasi yang baik. Hal ini diungkapkan Kepala Sekolah SMA Negeri 5 Pematangsiantar.

Peranan pendidikan menentukan usaha pengembangan mutu pendidikan. Untuk itu pendidikan sebagai agen pembelajaran dituntut untuk mampu menyelenggarakan proses pembelajaran dengan sebaik-baiknya, dalam kerangka perkembangan pendidikan. Pendidik mempunyai fungsi dan peran yang sangat strategis dalam pembangunan bidang pendidikan, dan oleh karena itu perlu dikembangkan sebagai profesi yang bermartabat. Undang- Undang No 14 Tahun 2005 tentang Guru dan Dosen pasal 4 menyiratkan bahwa pendidik sebagai agen pembelajaran berfungsi untuk meningkatkan mutu pendidikan nasional. Dalam mendukung harapan, Pemerintah Indonesia menetapkan standar kualifikasi akademik dan kompetensi pendidik sebagaimana ditetapkan dalam Peraturan Menteri Pendidikan Nasional Nomor 16 Tahun 2007 tentang Standar Kualifikasi Akademik dan Kompetensi Guru. Untuk dapat melaksanakan fungsinya dengan baik pendidik wajib untuk memiliki syarat tertentu salah satu diantaranya adalah kompetensi.

\section{Metode}

Metode yang digunakan dalam penelitian ini adalah metode kualitatif, yakn Senada dengan penjelasan Lexy J. Moleong, 
penelitian kualitatif adalah prosedur penelitian yang menghasilkan data deskripsi berupa kata-kata tertulis atau lisan dari orangorang dan perilaku yang diamati.Sementara itu penelitian deskriptif adalah suatu bentuk penelitian yang ditujukan untuk mendeskripsikan atau menggambarkan fenomena-fenomena yang ada baik fenomena almiah maupun rekayasa manusia penelitian kualitatif mewajibkan para peneliti membuat catatan kualitatif.

\section{Hasil dan Pembahasan}

\section{Perencanaan Program Supervisi Kepala Sekolah di SMA Negeri 5 Pematangsiantar}

Pelaksanaaan supervisi kepala sekolah melibatkan kepala sekolah dan wakil kepala sekolah sebagai supervisor, Guru yang disupervisi diharapkan mampu meningkatkan kompetensi guru serta dapat berkembang dalam kegiatan pembelajaran di SMA Negeri 5 Pematangsiantar. Perencanaan program supervisi ini salah satu penyusunan dokumen perencanaan, pemantauan dan serangkaian kegiatan yang dapat membantu guru dalam meningkatkan kemampuannya untuk mengelola proses pembelajaran guna mencapai hasil ataupun tujuan pembelajaran.

Pada penelitian ini dapat menunjukkan bahwa perencanaan supervisi kepala sekolah dalam meningkatkan kompetensi guru di SMA Negeri 5 Pematangsiantar sudah tersusun sesuai dengan ketentuan yang ada, Perencanaan dalam supervisi yang dilakukan pertama kepala sekolah menetapkan tujuan, kedua melakukan diskusi bersama para guru dan lainnya dengan musyawarah atau rapat, tiga melaksanakan jadwal supervisi yang dilakukan dalam satu semester yaitu diawal ajaran baru dan di akhir ajaran.

Persiapan pelaksanaan pembelajaran meliputi beberapa komponen yang diantaranya yaitu: kurikulum, silabus, pogram tahunan, program semester, dalam program pembelajaran (RPP) ,Perencanaan ini dilakukan oleh kepala sekolah SMA Negeri 5 Pematangsiantar dan sudah terjadwal sehingga semua guru-guru yang mengajar di SMA Negeri 5 ini mendapakan pengawasan dari kepala sekolah.

Dalam Pelaksanaan yang dilakukan kepala sekolah SMA Negeri 5 Pematangsiantar sudah sangat benar dimana pertama kalinya kepala sekolah memeriksa kelengkapan perangkat mengajar guru.kedua kepala sekolah mengadakan musyawarah kepada guru-guru, tiga kepala sekolah melakukan kunjungan kelas sesuai dengan jadwal yang telah ditentukan. Pelaksanaan supervisi yang dilakukan kepala sekolah biasanya diawal semester dan mengawasi mata pelajaran agama dan diakhir semester mengawasi mata pelajaran umum sehingga semua guru-guru yang ada di SMA Negeri 5 Pematangsiantar ini mendapat pengawasan dari kepala sekolah.

Pelaksanaan yang dilakukan oleh kepala sekolah ini di SMA Negeri 5 Pematangsiantar ini, dapat membantu para guru dalam mempersiapkan segala sesuatu yang dibutuhkan yang berkaitan dengan poses pembelajaran diruang kelas, dengan demikian adanya kegiatan supervisi ini sangat membantu para guru untuk lebih mengetahui letak dan kekurangan ataupun kelebihan dari dirinya dalam mempersiapkan suatu pogram pembelajaran.

Dapat dipahami bahwa supervisi kepala sekolah ini bertujuan untuk meningkatkan kompetensi guru serta memberikan masukan dan motivasi kepada guru agar selalu melaksanakan perbaikan dalam kinerjanya. Dan tujuan supervisi ini adalah untuk membantu bukan sebuah inspeksi, sehingga kepala sekolah dapat melakukan program supervisi dengan baik sehingga tujuan supervisi dapat tercapai dengan baik pula.

\section{Teknik Supervisi Kepala Sekolah di SMA Negeri 5 Pematangsiantar}

Dalam melaksanakan proses kegiatan supervisi kepala sekolah sebagai seorang supervisor dapat menggunakan teknik supervisi, Oleh karena itu setiap kepala sekolah harus memiliki kemampuan dan 
teknik berupa kemampuan dan dapat menerapkan teknik- teknik supervisi yang tepat dalam melaksanakan supervisi pendidikan. Secara garis besarnya cara ataupun teknik supervisi ini dapat digolongkan menjadi dua macam yaitu teknik perseorangan dan teknik kelompok.

Dalam Penelitian ini menunjukkan bahwa kepala sekolah SMA Negeri 5 Pematangsiantar melaksanakan kegiatan supervisi dengan menggunakan teknik supervisi yaitu secara individual dan secara kelompok dengan melihat situasi ataupun kondisi yang ada. Teknik secaa individual dilaksanakan dengan cara kunjungan kelas atau pun observasi. Kepala sekolah melihat bagaimana aktivitas langsung guru dalam mengajar, Sedangkan dengan teknik secara kelompok yaitu dengan cara mengelompokkan guru atau rapat. Jadi teknik yang bersifat individual dan kelompok, Akan mendukung tercapainya suatu tujuan supervisi yaitu memberi bantuan kepada tenaga kependidikan, khususnya guru semua mata pelajaran dapat memelihara kompetensi minimalnya, sehingga proses pembelajaran dapat berlangsung secara efektif dan efisien.

Berdasarkan hasil wawancara ini, observasi serta studi dokumentasi ini menunjukkan bahwa guru-guru harus lebih giat lagi dalam pembelajaran guna meningkatkan kompetensinya sebagai seorang guru yang profesional, Baik dengan pelatihan yang dilakukan untuk meningkatkan profesinya atau pelatihan- pelatihan yang diadakan oleh dinas, Sebab seorang guru adalah guru yang mampu memenuhi segala persyarataan standar baik dari kompetensi maupun dalam kinerjanya sebagai seorang guru.

Evaluasi Supervisi Kepala Sekolah di SMA Negeri 5 Pematangsiantar

Penelitian ini menunjukkan bahwa evaluasi supervisi di SMA Negeri 5 Pematangsiantar ini yang dilakukan kepala sekolah sudah terlaksana sesuai dengan prosedur yang ada. Evaluasi ini bertujuan untuk mengetahui apakah guru sudah melaksanakan proses pembelajaran dengan baik. Evaluasi yang dilakukan kepala sekolah dapat meningkatkan hasil kinerja guru yang sudah melakukan pembelajaran dengan mengadakan pemantauan serta kegiatan ujian siswa yang dilakukan dan pengolalaan hasil ujian siswa, Sehingga kedepannya dapat meningkatkan potensi yang di miliki agar tujuan pembelajaran dapat tersampaikan dengan baik kepada perserta didik dengan efektif dan efisien.

Menurut Bloom bahwa evaluasi ialah pengumpulan kenyataan secara sistematis untuk menetapkan apakah dalam kenyataanya terjadi perubahan dalam diri siswa dan menetapkan sejauh mana tingkat perubahah dalam pribadi siswa atau tidak.

Dari penjelasan diatas dapat disimpulkan bahwa supervisi kepala sekolah di SMA Negeri 5 Pematangsiantar sudah terlaksana dengan baik dalam Meningkatkan Kompetensi Guru khususnya dalam kompetensi pedagogik,kompetensi profesional, kompetensi sosial, kompetensi kepribadian. Karena evaluasi yang diberikan oleh kepala sekolah sangat penting untuk dilaksanakan, Karena evaluasi ini memberikan dampak yang sangat positif untuk meningkatkan kompetensi guru di SMA Negeri 5 Pematangsiantar. Dengan adanya supervisi ini membantu para guru untuk meningkatkan kompetensinya dan dapat di lihat dari perubahan cara guru mengajar. Sebab acuan dari sikap ini salah satunya ialah kompetensi pedagogik, yaitu Sertifikasi syarat menjadi guru yang mempunyai kompetensi, ada 59 orang guru yang sudah bersertifikasi dan mampu bersikap profesional.

Maka dari itu evaluasi ini dapat memotivasi para guru dan menjadikan sebuah masukan bagi guru untuk tindakan mereka yang mana yang harus dipertahankan dan yang mana yang harus dihilangkan. Selain itu juga dievaluasi dari kegiatan supervisi kepala sekolah yang dilakukan sangat berdampak 
bukan hanya kepada guru, tetapi kepada lembaga juga, Sebab apabila lembaga memiliki guru yang profesional, Maka lembaga pendidikan memiliki mutu yang lebih baik lagi.

\section{Simpulan}

Berdasarkan pemaparan data dan temuan penelitian ini dapat penulis ambil beberapa simpulan,yakni :

1. Perencanaan supervisi kepala sekolah dalam meningkatkan kompetensi guru di SMA Negeri 5 Pematangsiantar, Sudah dilaksanakan dan sangat tersusun dengan baik sesuai dengan ketentuan yang berlaku adapun supervisi yang dilaksanakan kepala sekolah dengan menerapkan beberapa perencanaan pertama kepala sekolah menetapkan tujuan, kedua melakukan diskusi bersama para guru melalui musyawarah dan rapat, ketiga melaksanakan jadwal supervisi yang akan dilaksanakan dalam satu semester terdapat 2 kali yaitu diawal ajaran baru dan diakhir ajaran.

2. Teknik supervisi kepala sekolah dalam meningkatkan kompetensi guru di SMA Negeri 5 Pematangsiantar. Sudah dilaksanakan melalui teknik supervisi yang bersifat individual dengan mengadakan kunjungan kelas atau pun observasi kelas dan teknik supervisi ini dilaksanakan dengan cara kelompok. Adapun kegiatan yang dilakukan yaitu terlebih dahulu memeriksa perangkat pembelajaran yang dibuat oleh guru yaitu guru-guru yang sudah melakukan persiapan sebelum pembelajaran dilakukan seperti membuat silabus, Rencana Program Pengajaran (RPP) yang sebagai acuan untuk pedoman dalam kegiatan mengajar serta media pembelajaran, prota, prosem, kemudian kepala sekolah melakukan kunjungan kelas untuk menilai guru didalam kelas selama proses pembelajaran berlangsung. Tetapi dikarenakan saran dan prasarana yang kurang memadai sehingga dalam pelaksanaan supervisi terhambat, selain itu juga karena jadwal kepala sekolah yang terlalu padat sehingga pelaksanaan suprvisi tidak sesuai jadwal yang sudah ditetapkan.

3. Evaluasi supervisi kepala sekolah dalam meningkatkan kompetensi guru di SMA Negeri 5 Pematangsiantar, sudah dilaksanakan dengan baik dengan baik melalui penilaian yang dilakukan kepada guru jadi untuk mengetahui sejauh manakah kompetensi guru telah berjalan apakah sudah lebih baik atau belum, Evaluasi yang dilakukan kepala sekolah agar dapat meningkat maka hasil dari kinerja guru melalui proses pembelajaran dengan mengadakan pemantauan kegiatan ujian siswa dan pengelolahan hasil ujian siswa ini. Sehingga kedepanya dapat meningkatkan kompetensi guru agar tujuan pembelajaran ini dapat tersampaikan kepada perserta didik dengan efektif dan efisien. Dalam hal ini kegiatan supervisi yang dilakukan oleh kepala sekolah sangat membantu para guru untuk pengetahui seberapa kemampuannya hal ini dapat terlihat dari cara guru mengajar.

\section{Daftar Pustaka}

Arikunto, Suharsimi, Manajemen penelitian, Jakarta: Rineka Cipta, 2013

Donni Juni Priansa, Menjadi Kepala Sekolah dan Guru Profesional, Konsep,Peran Strategis,dan Pengembangannya, Bandung: CV Pustaka Setia, 2017

Donni Juni Priansa, Risma Somad, Manajemen Supervisi dan Kepemimpinan Kepala Sekolah, Bandung: CV Alfabeta, 2014

Edy Sukamto, Supervisi Akademik Kepala Sekolah dan Kompetensi Profesional Guru, Jawa Barat: CV Adanu Abimata, 2020

E. Mulyasa. Manajemen berbasis sekolah: konsep, strategi, dan implementasi, CV Rosda, 2014 
H. Mukhtar, Iskandar, Orientasi Baru Supervisi Pendidikan Jakarta: Gaung Persada Press Group, 2013

Imam Gunawan, Metode Penelitian Kualitatif, Teori \& Praktik Jakarta: Bumi Aksara, 2015

M. Mujiam (2015)“Pelaksanaan Supervisi Pembelajaran Oleh Kepala Sekolah Dalam Meningkatkan Kompetensi Profesional Guru Di SMP Negeri Kecamatan Kaway Xvi" https:// jurnal .ar-raniry.ac.id diakses pada tanggal 12 April 2021

Nu Afriadi (2016) "Kompetensi Supervisi Kepala Sekolah dalam Meningkatkan Profesionalisme Guru Pada SMA Negeri 1Kuala Batee Kabupaten http:// jurnal unsyiah.ac.id. Jejen Musfah, Peningkatan Kompetensi Guru, Melalui Pelatihan \& Sumber Belajar Teori dan Praktek, Jakarta : Prenadamedia Group 2011

Y Bermawi (2015) Supervisi Kepala Sekolah Terhadap Kompetensi Profesional Guru di SD Negeri Banda Aceh " Jurnal Pendidikan Dasar dan Humaniora, http :// jurnal.unsyiah.ac.id. diakses pada tanggal 12 April 2021

Piet A. Sahertian, Konsep Dasar dan Teknik Supervisi Pendidikan Dalam Rangka
Pengembangan Sumber Daya Manusia, Jakarta: Rineka Cipta 2008

Rina Febriana, Kompetensi Guru, Jakarta: Bumi Aksara 2019

Syaiful Bahri Djamarah, Guru \& Anak Didik Dalam Interaksi Edukatif Suatu Pendekatan Teoritis Psikologis, Jakarta, Rineka Cipta 2010

Supardi, Kinerja Guru Kepala sekolah, Jakarta, Raja Grafindo 2019

S. Haji (2015) "Supervisi Kepala Sekolah untuk Meningkatkan kompetensi Pedagogik Guru di SDN 1 Pulau Rimau"https:// jurnal.univpgri- palembang.ac.id diakses pada tanggal 12 April 2021

Salim Aktar (2018) Standar Sistem Mutu dan Pengembangan Sistem Mutu di Organisasi Pendidikan.http:jurnal.umsu.ac.id

Undang-Undang No 19 Tahun 2005 Standar Nasional Pendidikan tentang Kompetensi pedagogik, kepribadian, sosial dan profesional

Undang - undang No 14 Tahun 2005 tentang Guru dan Dosen

Undang-undang No 20 Tahun 2003 dan Pemerintah RI No 19 Tahun 2005 Bab VI tentang Standar Pendidik dan tenaga Pendidikan. 